\title{
Physical Property Characterization of the Waipapa Greywacke: An Important Geothermal Reservoir Basement Rock in New Zealand
}

\author{
Aurelio Melia ( $\sim$ aurelio.melia@libero.it) \\ University of Liverpool (UK) https://orcid.org/0000-0003-2488-8799 \\ Daniel Roy Faulkner \\ University of Liverpool (UK) \\ David Daniel McNamara \\ University of Liverpool (UK)
}

\section{Research}

Keywords: Geothermal, Greywacke, Permeability, Fracture, Rock Properties, Basement Rock.

Posted Date: November 17th, 2021

DOI: https://doi.org/10.21203/rs.3.rs-1071508/v1

License: (c) (i) This work is licensed under a Creative Commons Attribution 4.0 International License.

Read Full License 


\section{Physical property characterization of the Waipapa Greywacke: an important geothermal reservoir basement rock in New Zealand}

Melia, Aurelio ${ }^{1}$, Faulkner, Daniel Roy ${ }^{1}$, McNamara, David Daniel $^{1}$.

${ }^{1}$ Department of Earth, Ocean and Ecological Sciences, University of Liverpool, Liverpool, L69 3GP.

Keywords: Geothermal; Greywacke; Permeability; Fracture; Rock Properties; Basement Rock.

Institutional email addresses: faulkner@liverpool.ac.uk ; d.mcnamara@liverpool.ac.uk

Personal email addresses: aurelio.melia@libero.it

Corresponding author: Aurelio Melia

Submission Date: November 12th, 2021.

ABSTRACT

Greywacke basement rocks in New Zealand host conventional geothermal reservoirs and may supply important hotter and deeper geothermal energy resources in the future. This work combines petrological analyses and physical property measurements of Waipapa greywacke, a basement unit hosting New Zealand geothermal reservoirs, in order to understand better how structurally controlled flow networks develop and channel geothermal fluids within it. Results show intact Waipapa greywacke has high tensile and triaxial compressive strengths, and low intrinsic permeability $\left(\sim 10^{-21} \mathrm{~m}^{2}\right)$. Permeability of intact Waipapa greywacke does not increase significantly during triaxial loading to failure and is accompanied by minimal changes ultrasonic wave velocities. These data taken together suggest that microcrack development during brittle deformation is very limited. Upon failure, the permeability increases by two orders of magnitude and shows similar permeability to tests performed on synthetic, single, mode I fractures in intact Waipapa greywacke.

(1)

Permeability persists in Waipapa greywacke fractures under confining pressures of at least 150 
MPa. It is concluded that Waipapa greywacke rocks will not allow fluid flow through the matrix of the rock and that substantial geothermal fluid flow will only occur through macrofracture networks.

\section{INTRODUCTION}

In New Zealand, both direct use (e.g. heating, bathing, horticulture) and electricity production from geothermal resources is well developed and continues to expand [Carey et al., 2015]. Current geothermal development for electricity production in New Zealand utilizes reservoirs at depths up to $\sim 3.5 \mathrm{~km}$, dubbed the conventional resource. Future development of geothermal power in New Zealand aims at expanding the use of basement hosted geothermal resources, including the greywacke basement terranes of the North Island [Mroczek et al., 2016; Brathwaite et al., 2002; Wood et al., 2001], and newer discoveries proposed in the basement schist lithologies of the South Island [Sutherland et al., 2017]. Furthermore, future New Zealand geothermal potential lies in the development of deeper and hotter reservoirs likely hosted within similar basement lithologies [Bignall, 2011; Sheburn et al., 2003].

In basement geothermal reservoirs hosted in greywacke or igneous rocks, fracture and fault networks control fluid flow [Wood et al., 2001; Sutherland et al., 2017; Wallis et al., 2011; Browne, 1980]. As such, these resources are susceptible to changeable heat fluxes, dynamic fluid flow regimes, and tectonic stress fields, all of which can exert influence on the physical and mechanical properties of these fractured reservoir host rocks. Information on the physical and mechanical properties of basement rocks in New Zealand is thus crucial to their future development as geothermal resources both at conventional development depths and at novel, deeper depths. Furthermore, such dynamic environments generate fluid-rock interactions, which can alter the mineralogy and texture of reservoir host rocks, in turn modifying the physical properties, which 
govern their mechanical behaviour and subsequent structural network development [Siratovich et al., 2015]. In order to optimize and maintain structurally hosted geothermal resources, studies of their physical properties, their interactions, and their dynamic evolution due to fluid interactions need to be studied to understand the effects they produce in the subsurface reservoir [Gupta and Sukanta, 2006; Di Pippo, 2008; Grant and Bixley, 2011].

To date, few data on the thermo-physical properties of New Zealand greywacke basement rocks exist [Mielke et al., 2016, McNamara et al., 2014; Richards and Read, 2007]. This study aims to enhance the understanding of the physical properties of these important geothermal reservoir rocks by presenting new data on the physical, mechanical, and elastic properties on the Waipapa greywacke terrane. This basement terrane is known to host geothermal reservoirs in the Ngawha Geothermal Field in Northland, and has the potential to host deeper geothermal resources in the Taupo Volcanic Zone (TVZ). Rock texture and microstructure analysis, combined with physical property determination (uniaxial compressive strength (UCS), tensile strength, triaxial compressive strength, static and dynamic elastic properties, porosity, density, seismic wave velocity, and permeability) of Waipapa Terrane greywacke samples presented here provide new information on the physical properties controlling brittle deformation in this lithology, the process necessary for it to act as a geothermal reservoir. Data presented here will contribute towards the improved construction of thermo-hydro-mechanical-chemical models of this basement terrane to assist in derisking of future New Zealand geothermal systems and other similarly hosted geothermal reservoirs globally.

\section{$1.1 \quad$ Geological Setting}

The Waipapa Terrane in New Zealand spans a significant portion of the northwest half of New Zealand's North Island, outcropping from the northwest border of the TVZ, and northwards into Northland (Figure 1). Permian to Jurassic units comprise the terrane in a complex sequence of indurated and metamorphosed volcaniclastic sandstones and siltstones [Adams et al., 2009; 
Beetham and Watters, 1985]. Following Begg \& Mazengarb (1996), in New Zealand the greywacke sequences are generally identified as medium to dark grey, coarse to medium grained, lightly metamorphosed sandstones. Grains are poorly sorted and consist of angular quartz and feldspar, and lithic fragments of metamorphic and igneous rocks. The intergranular material consists of clay minerals formed during induration or low-grade metamorphism. Greywacke sandstones may be interbedded with lightly metamorphosed mudstones (argillite), usually layers of clay, silt, or mud, generally dark to black in colour, yet occasionally red when there is a high content of iron bearing minerals. The proportions between mudstone and sandstone are spatially variable within the Waipapa Terrane. Geothermal expression in this unit is well documented at the Ngawha Geothermal Field in Northland, and potentially within the buried basement units underneath the modern (>2 Ma) volcaniclastic deposits of the TVZ.

Locally, at the Ngawha Geothermal Field, Waipapa Terrane basement hosting the geothermal resource is composed of grey-green argillites and massive, quartzo-feldspathic greywacke sandstones which have experienced low-grade metamorphism (prehnite-pumpellyite grade [Mayer, 1968]), and are strongly hydrothermally altered and veined with common fault breccia textures [Bayrante and Spörli, 1989; Cox and Browne, 1998; Sheppard, 1986]. Waipapa greywacke basement is not yet drilled within the TVZ, an extensional intra-arc basin formed as a consequence of oblique subduction of the Pacific Plate underneath the North Island of New Zealand [Sheppard, 1986; Wilson et al., 1995]. Torlesse Terrane greywacke basement rock has been penetrated by drilling in the Kawerau, Ngatamariki, Ohaaki, Rotokawa, and Tauhara geothermal fields [Wood et al., 2001; Adams et al., 2009; Cole and Spinks, 2009; Cant et al., 2018; McNamara and Massiot, 2016; McNamara et al., 2016, Bignall et al., 2010], and at Kawerau Geothermal Field hosts geothermal resources. The suture between the Waipapa and Torlesse terranes is thought to occur somewhere within the TVZ underneath the infill units but a precise location and depth is undetermined [Adams et al., 2009; Milicich et al., 2013a]. However, given that seismic evidence points to brittle deformation reaching potential depths of $\sim 6$ to $8 \mathrm{~km}$ [Bibby et al., 1995], Waipapa 
107 terrane greywacke holds significant potential as a reservoir for hotter and deeper geothermal 108 resources within the TVZ [Bignall, 2011].

109 Limited data exist on the thermo-physical properties of the Waipapa terrane greywacke 110 lithologies. A $3.7 \%$ porosity measurement, which included a structural component, was measured 111 by McGuiness [McGuinness, 1984]. UCS values of Waipapa terrane greywacke of $193 \mathrm{MPa}$ are 112 recorded by Richards and Read (2007). McNamara et al. (2014) describe densities of $\sim 2.71 \mathrm{~g} / \mathrm{cm}^{3}$, 113 tensile strength ranges of 20-36 MPa, UCS values of 300-310 MPa, static Poisson's ratio and 114 Young's moduli of 0.28 and $70 \mathrm{GPa}$ respectively, cohesion values of $51 \mathrm{MPa}$, a 0.93 coefficient of 115 internal friction $(\mu)$, nuclear magnetic resonance porosities of $2 \%$, and P-wave velocities $\left(V_{p}\right)$ ranges 116 of $6-6.25 \mathrm{~km} / \mathrm{s}$. Mielke et al. (2016) document similar values for the properties noted in 117 McNamara et al. (2014) with the only exceptions being lower $V_{p}$ values $(\sim 5.6 \mathrm{~km} / \mathrm{s})$, lower UCS 118 values (123-245 MPa), and lower Young's Modulus ( 20-27 GPa). Porosity values of $\sim 1 \%$, 119 permeability of $<1 \times 10^{-16}$, thermal conductivity $\left(\sim 2.5 \mathrm{Wm}^{-1} \mathrm{~K}^{-1}\right)$ and diffusivity $\left(\sim 1.14-1.24 \times 10^{-6}\right.$ $120 \mathrm{~m}^{2} / \mathrm{s}$ ), specific heat capacity of $\sim 0.74-0.87 \mathrm{~kg} \cdot \mathrm{m}^{2} / \mathrm{K} \cdot \mathrm{s}^{2}$, and a shear-wave velocity $\left(V_{S}\right)$ of $3 \mathrm{~km} / \mathrm{s}$ are 121 also recorded. 


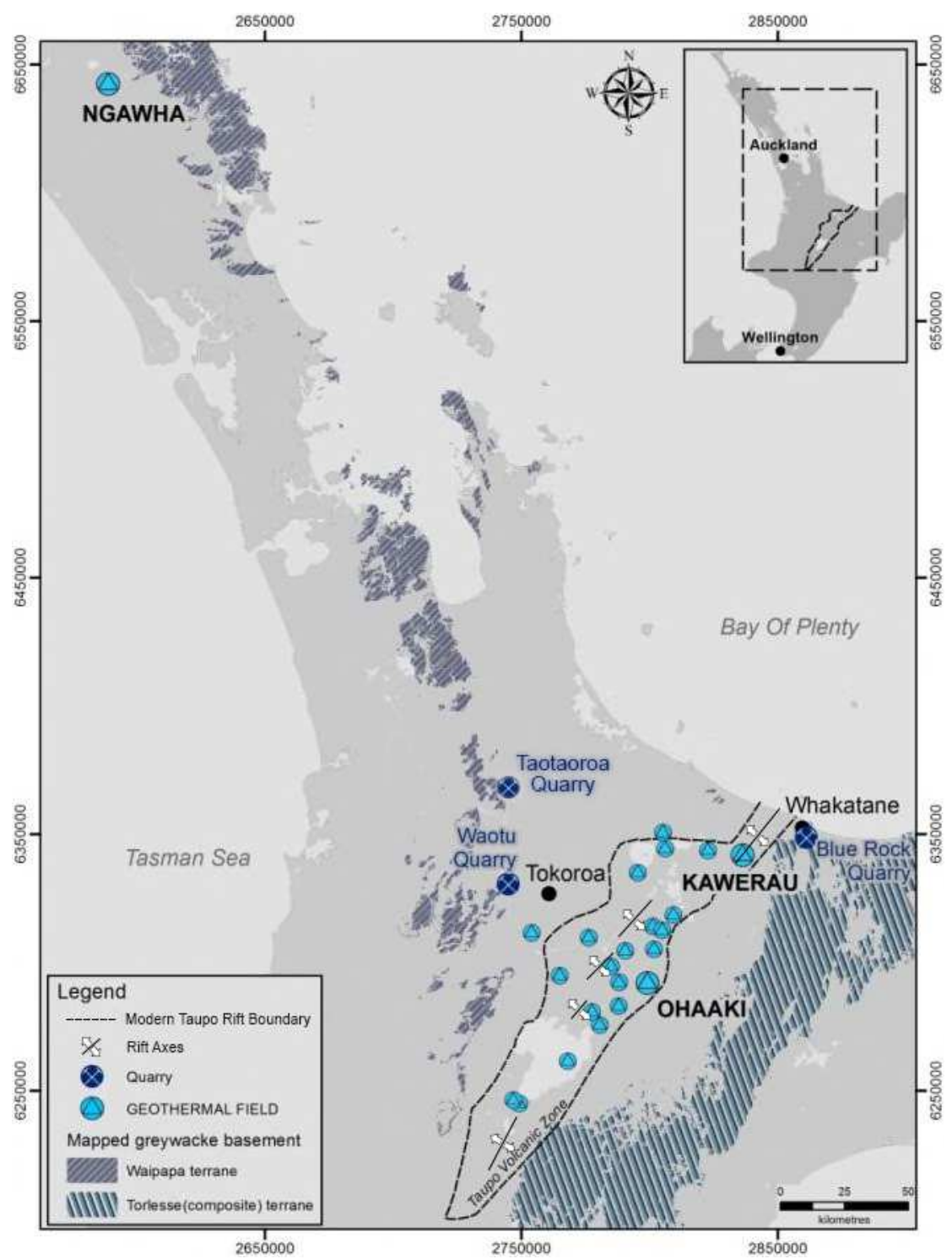

Figure 1: Map of the North Island of New Zealand showing outcropping basement terrane rocks, major structural components of the TVZ, geothermal field locations, and the locations of the quarries used for sampling for this work. Modified from McNamara et al. (2014).

\section{METHODS AND MATERIALS}

\subsection{Materials and Sample Preparation}

Samples of Waipapa greywacke terrane were acquired from quarry outcrops in order to test

132 their physical and mechanical properties. Waipapa samples are sourced from Taotaoroa Quarry

133 (TTGW), which is located between Cambridge and Matamata, $\sim 8 \mathrm{~km}$ north of Karapiro Lake.

134 While outcrops where samples are acquired show the Waipapa greywacke to be layered and 
135 fractured, the samples tested here contain no discernible anisotropy with respect to internal fabrics.

136 All the rock deformation data presented in this work were collected at the Rock Deformation 137 Laboratory at the University of Liverpool, and SEM images were collected using a JEOL JSM

138 7001F FEG-SEM in the SEM Shared Research Facility, Albert Crewe Centre for Electron Microscopy at the University of Liverpool. Twenty-five, $20 \mathrm{~mm}$ diameter $\mathrm{x} 50 \mathrm{~mm}$ height specimens were cored and squared from samples of Waipapa greywacke sandstones from Taotaoroa Quarry. Squareness of the cored samples was better than $0.01 \mathrm{~mm}$ or less [Paterson and Wong, 2015]. A selection of these specimens was used to make ten, $20 \mathrm{~mm}$ diameter $\mathrm{x} 10 \mathrm{~mm}$ height disks utilized for tensile strength measurements, and two cores (of the same size) for permeability measurements where a macroscopic mode I fracture was induced in the samples. Three thin sections of Waipapa greywacke from Taotaoroa Quarry were made for petrological observations using an optical microscope. Finally, the sample taken to failure during triaxial testing was impregnated with epoxy resin and cut parallel to the core axis and perpendicular to the shear fracture plane, polished and utilized for imaging of the deformed specimen in an XL30 Philips scanning electron microscope (SEM).

\subsection{Porosity measurements and bulk density}

Porosity estimates are determined from cores using a helium multipycnometer model (MVPD160-E, Quantachrome Instruments). The porosity was calculated for seventeen samples of Waipapa greywacke. Bulk density was calculated for three Waipapa greywacke cores, using their mass and solid volume.

\subsection{Tensile strength}

Brazilian tests, conforming to ATSM standards (ATSM D3967-08), were performed on 20 $\mathrm{mm}$ diameter disks of greywacke basement rock, with a thickness-to-diameter ratio (t/D) between 0.2 and 0.75 . Tensile strength is calculated with the following equation: 


$$
\sigma_{t}=\frac{2 \mathrm{P}}{\pi \mathrm{LD}}
$$

163

where: $\sigma_{t}$ is the splitting tensile strength $(\mathrm{MPa}), \mathrm{P}$ is the maximum force applied indicated by the machine $(\mathrm{N}), \mathrm{L}$ is the thickness of the specimen $(\mathrm{mm}), \mathrm{D}$ is the diameter of the specimen $(\mathrm{mm})$.

\subsection{Uniaxial compressive strength}

UCS experiments were carried out on ten samples from Taotaoroa Quarry. Axial and circumferential strain gauges were attached to the samples during testing. Samples were then brought to failure using a uniaxial press. Static Young's modulus $(E)$ and static Poisson's ratio $(v)$ are estimated from the gradient of a linear elastic region of the UCS test results (from 40-120 MPa).

\subsection{Triaxial loading test}

A single triaxial compressive test $\left(\sigma_{1}>\sigma_{2}=\sigma_{3}\right)$ was carried out on a greywacke core in order to obtain the lithology's strength under confining pressure conditions of $20 \mathrm{MPa}$ and a pore pressure of $5 \mathrm{MPa}(\bar{\sigma}=15 \mathrm{MPa})$ to enhance our understanding of how this lithology undergoes shear fracture at $\sim 1 \mathrm{~km}$ depth, and to ensure repeatability of results delivered in McNamara et al. (2014). Furthermore, the evolution of permeability and P and S wave velocity were monitored to establish the development of these properties during loading to failure. We used a triaxial deformation rig able to perform triaxial experiments up to $250 \mathrm{MPa}$ confining pressure (servo controlled), $250 \mathrm{MPa}$ pore pressure (servo controlled), and $1000 \mathrm{MPa}$ differential stress with a load capacity of $300 \mathrm{kN}$ [Faulkner and Armitage, 2013] (Figure 2). Figure 2 shows the layout of this apparatus, illustrating where the sample is situated within the pressure vessel. It also shows the 
internal force gouge that provided high resolution measurements of the axial force that was applied to the sample via a screw-driven actuator below the vessel illustrated in Figure 2.

$V_{p}$ and $V_{s}$, and permeability measurements of the sample are measured axially during this experiment. The position of the piezoelectric crystals (lead-zircon titanate) within the assembly are illustrated in Figure 2. Axial loading proceeded at a displacement rate of 0.1 microns/s and paused at various intervals in order to obtain $P$ - and $S$ - wave velocity and permeability measurements (detailed in Section 2.7). The axial displacement reported is corrected for the elastic distortion of the loading column, which is $180 \mathrm{kN} / \mathrm{mm}$ for the apparatus.

\subsection{Elastic wave velocities and dynamic elastic moduli}

Ultrasonic wave velocities ( $P$ - and $S$ - wave) were measured along sample axes while loaded to failure in both uniaxial compression and triaxial testing. These tests were carried out in order to understand how the wave velocities develop as microcrack networks develop under increasing stress, providing insight into the change in microcrack density in the samples during deformation (e.g. Schubnel et al., 2003). Values are determined under varying levels of axial stress during UCS testing, and under various levels of axial stress with constant confining pressures during triaxial testing. Physical property characterizations are summarized in Table 2.

Velocity data were used to calculate a dynamic Young's modulus $\left(E_{d}\right)$ and dynamic Poisson's ratio $\left(v_{d}\right)$ for these samples, using the below equations and assuming isotropy [Kuttruff, 1991]:

$$
E_{d}=\frac{\rho V_{s}^{2}\left(3 V_{p}^{2}-4 V_{s}^{2}\right)}{V_{p}^{2}-V_{s}^{2}}
$$


212 where $\rho$ is the density $\left(\mathrm{g} / \mathrm{cm}^{3}\right)$. The change in the sample's density, calculated from the variation in 213 volumetric change which occurs during uniaxial compression, was accounted for in the analysis.

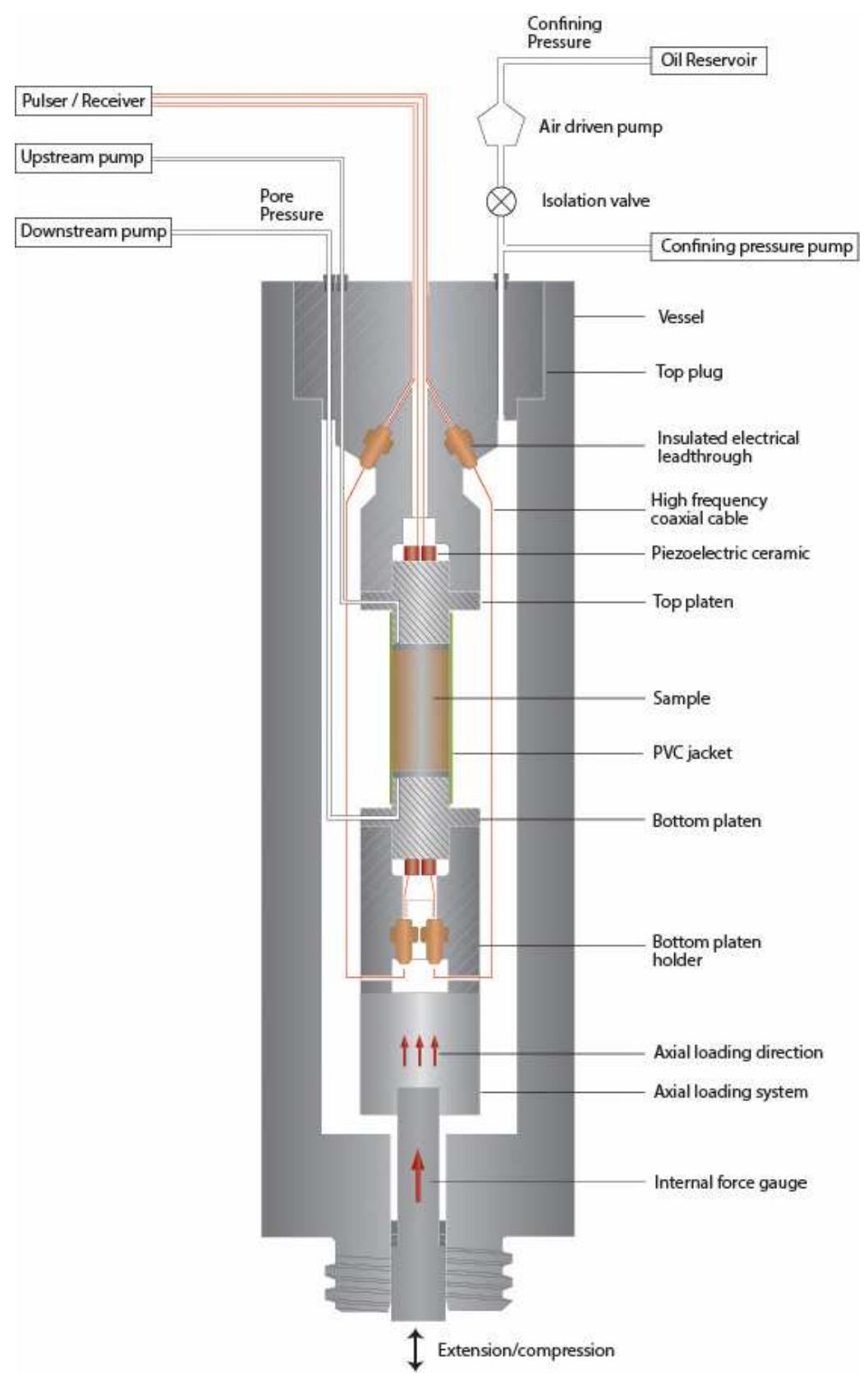

216 Figure 2: A schematic illustration of the sample assembly contained within the pressure vessel used for the 217 experiments described. It also highlights the position of the piezoelectric crystals within the assembly that 218 are used for the $P$ and $S$ wave velocity measurements [Faulkner and Armitage, 2013]. 


\subsection{Permeability measurements}

To examine fluid flow properties of the Waipapa Terrane greywacke, permeability tests were carried out on both intact samples and samples containing a synthetic single fracture. Permeability measurements were performed using the pulse-transient method [Brace et al., 1968] with deionised water used as the pore fluid. When the measurement begins, the upstream and downstream reservoir pressures of the sample are equilibrated and equal. A small increase $(<1$ $\mathrm{MPa}$ ) of the upstream reservoir pressure or a decrease of the downstream reservoir pressure is then imposed to apply a pressure gradient across the sample. The decay characteristics of this pressure pulse, monitored in the upstream or downstream reservoir or both, may then be used to obtain a value for permeability.

As previously mentioned, permeability measurements were made during the triaxial compression tests to monitor permeability evolution as intact greywacke approaches failure. Permeability measurements were made for each pressure step (every $20 \mathrm{kN}$, or $63.91 \mathrm{MPa}$ increase in load). The first permeability measurement was taken at $0 \mathrm{MPa}$ (no load applied), with subsequent measurements made at compressive stresses of 20 (63.91 MPa), 40 (127.81 MPa), 60 (191.72 MPa), $80(255.62 \mathrm{MPa}), 90(287.57 \mathrm{MPa}), 95(303.55 \mathrm{MPa})$ and finally $100 \mathrm{kN}$ (319.52 $\mathrm{MPa})$ where brittle failure occurred.

In order to understand how the permeability of single fracture responds to varying stress conditions, two intact greywacke rock cores (20 mm diameter x $10 \mathrm{~mm}$ height) were placed in a Brazilian loading jig, then loaded to failure in order to produce a single fracture plane [Nara et al., 2011]. These samples were then carefully placed in a polyurethane jacket and put into a triaxial testing apparatus to hydrostatically load the specimen and measure evolving fracture permeability. For both specimens, permeability was recorded initially at $40 \mathrm{MPa}$ confining pressure, with subsequent measurements taken every $5 \mathrm{MPa}$ up to $110 \mathrm{MPa}$. After that, permeability measurements were taken at 120,130 and $150 \mathrm{MPa}$. The procedure used here follows that of Nara et al. [Nara et al., 2011]. 


\begin{tabular}{|c|c|c|c|c|c|c|c|c|c|c|}
\hline Sample & Uniaxial & Triaxial & Brazilian & $V p-V s$ & Porosity & Permeability & SEM & XPL & S.F. & Density \\
\hline TTGW_11_3_H1160 & & & & & & & & $\checkmark$ & & \\
\hline TTGW_11_3_H1161 & & & & & & & & $\checkmark$ & & \\
\hline TTGW_11_3_4_triax & & $\checkmark$ & & $\checkmark$ & $\checkmark$ & $\checkmark$ & $\checkmark$ & $\checkmark$ & & \\
\hline TTGW_11_2_1 & $\checkmark$ & & & & & & & & & \\
\hline TTGW_11_2_2 & $\checkmark$ & & & & & & & & & \\
\hline TTGW_11_2_3 & $\checkmark$ & & & & & & & & & \\
\hline TTGW_11_2_4 & $\checkmark$ & & & & & & & & & \\
\hline TTGW_11_3_1 & & & & & $\checkmark$ & & & & & \\
\hline TTGW_11_3_2 & & & & & $\checkmark$ & & & & & \\
\hline TTGW_11_3_3 & & & & & $\checkmark$ & & & & & \\
\hline TTGW_11_3_5 & & & & & $\checkmark$ & $\checkmark(x 18)$ & & & $\checkmark$ & \\
\hline TTGW_11_3_6 & $\checkmark$ & & & & $\checkmark$ & & & & & \\
\hline TTGW_11_3_7 & & & & & $\checkmark$ & & & & & \\
\hline TTGW_11_3_8 & & & $\checkmark(\times 3)$ & & $\checkmark$ & & & & & \\
\hline TTGW_11_3_10 & & & & $\checkmark$ & $\checkmark$ & & & & & \\
\hline TTGW_11_3_11 & $\checkmark$ & & & & & & & & & $\checkmark$ \\
\hline TTGW_11_3_12 & $\checkmark$ & & & $\checkmark$ & & & & & & $\checkmark$ \\
\hline TTGW_11_3_13 & $\checkmark$ & & & $\checkmark$ & & & & & & $\checkmark$ \\
\hline TTGW_11_3_14 & $\checkmark$ & & & $\checkmark$ & & & & & & \\
\hline TTGW_11_3_16 & & & & & $\checkmark$ & & & & & \\
\hline TTGW_11_3_17 & & & & & $\checkmark$ & $\checkmark(x 18)$ & $\checkmark$ & & $\checkmark$ & \\
\hline TTGW_11_3_18 & & & $\checkmark(\times 3)$ & & $\checkmark$ & & & & & \\
\hline TTGW_11_3_19 & & & & & $\checkmark$ & & & & & \\
\hline TTGW_11_3_20 & & & $\checkmark$ & & $\checkmark$ & & & & & \\
\hline TTGW_11_3_21 & & & $\checkmark$ & & $\checkmark$ & & & & & \\
\hline TTGW_11_3_22 & & & & & $\checkmark$ & & & & & \\
\hline TTGW_11_3_23 & & & $\checkmark(\times 2)$ & & $\checkmark$ & & & & & \\
\hline
\end{tabular}


$254 \quad 3 \quad$ RESULTS

\section{$255 \quad 3.1 \quad$ Petrology}

From examination, Waipapa Terrane samples used in this study are composed of a medium 257 to coarse grained $(0.25-1.5 \mathrm{~mm})$, greywacke sandstone consisting of abundant to common, 258 subangular-subrounded, detrital quartz, plagioclase, and abundant lithic fragments ( $\leq 5 \mathrm{~mm}$ sizes) 259 (Figure 3). Lithic fragments are made of andesitic, basaltic, and rhyolitic lavas with granophyric 260 textures, and siltstone. Some lava lithics show a trachytic texture. The greywacke sandstone is clast 261 supported and matrix poor. Matrix is composed of indurated clay/silt. Chlorite, calcite, quartz, and 262 occasional epidote are found as vein minerals. In general, the Waipapa samples are moderately 263 altered to chlorite, leucoxene and clay with some weak epidote alteration. Plagioclase crystals in 264 places are weakly altered to clays while detrital biotite crystals are relatively fresh. Within the rock 265 andesite lithic fragments show some albitization. The groundmass is altered to chlorite and detrital 266 plagioclase is partially altered to clay. Mineralization within observed microfractures in these 267 samples indicates that these crack networks at one point operated as fluid flow pathways. 

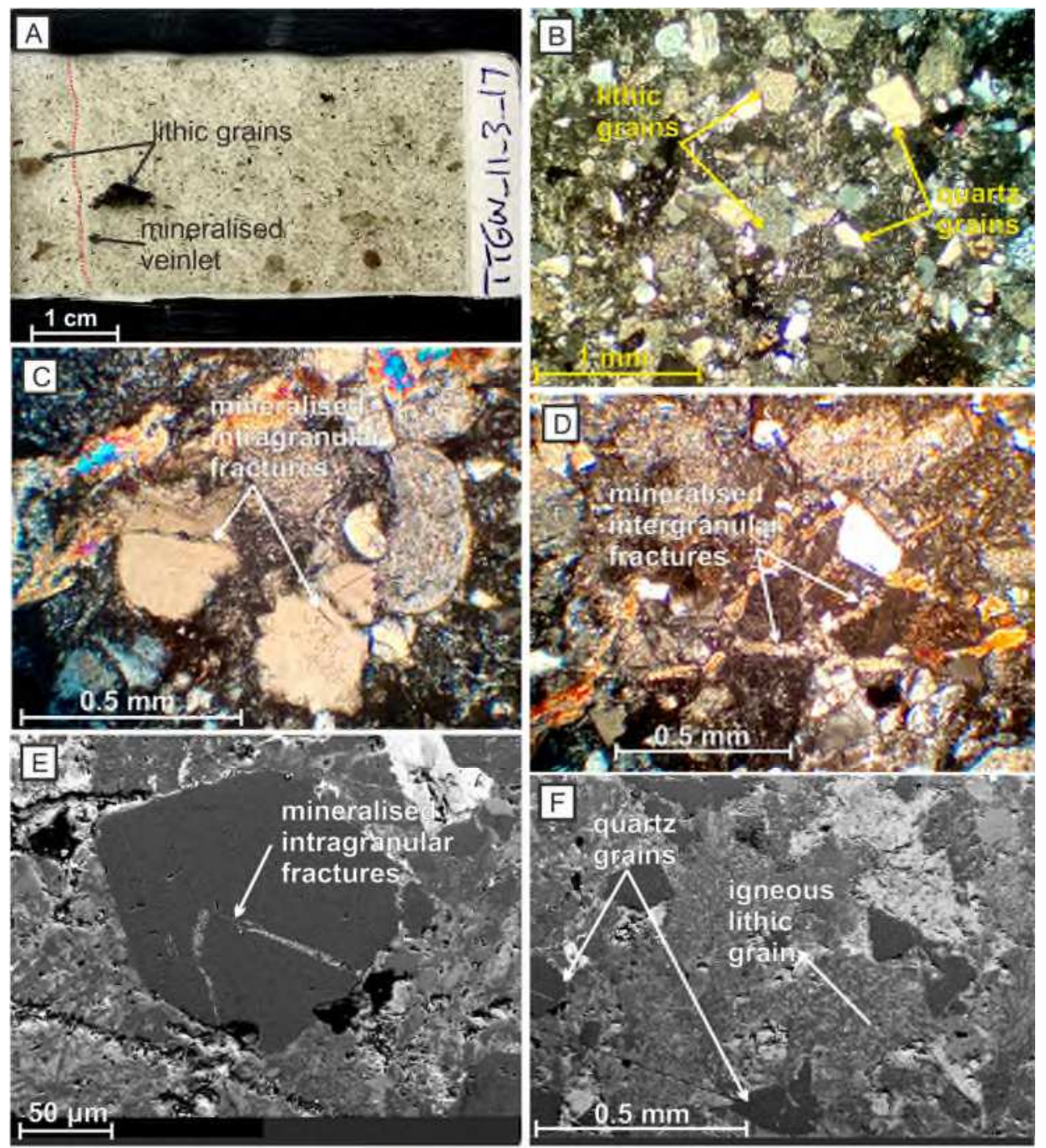

Figure 3: A) Photograph of thin section of sample TTGW_11_3_17 showing grain size variation and 271 mineralised veinlets (red line), B) Photomicrograph (XP; TTGW_11_3_17) showing typical grain size and texture 272 of Waipapa basement greywacke C) Photomicrograph (XP; TTGW_11_3_17) showing mineralised 273 intragranular fractures in quartz grains, D) Photomicrograph (XP; TTGW_11_3_17) showing mineralised 274 intergranular veinlets in Waipapa greywacke, E) SEM backscatter image (TTGW_11_3_17) showing 275 mineralised intragranular fractures within a quartz grain, F) SEM backscatter image ( TTGW_11_3_17) showing typical 276 grain sizes and textures of Waipapa greywacke basement and the igneous textures noted in lithic grains. Qz = quartz, Pl $277=$ plagioclase.

\subsection{Porosity and bulk density}

Table 2 provides an overview of the mechanical (tensile and unconfined strength), elastic,

281 and physical properties of intact Waipapa greywacke.

\begin{tabular}{|l|c|c|c|c|}
\hline \multicolumn{1}{|c|}{ Property } & $\begin{array}{c}\text { Measured } \\
\text { Range }\end{array}$ & $\begin{array}{c}\text { \# of } \\
\text { Tests }\end{array}$ & Mean & $\begin{array}{c}\text { Standard } \\
\text { Deviation }\end{array}$ \\
\hline Tensile Strength & $14.4-32.42$ & 10 & 21.07 & 8.28 \\
\hline
\end{tabular}




\begin{tabular}{|l|c|c|c|c|}
\hline (MPa) & & & & \\
\hline UCS (MPa) & $205-384$ & 10 & 285.6 & 60.17 \\
\hline Poisson's Ratio ( $\left.v_{S}\right)$ & $0.19-0.36$ & 10 & 0.316 & 0.1 \\
\hline $\begin{array}{l}\text { Young's Modulus } \\
\left(E_{S}\right)(\mathrm{GPa})\end{array}$ & $54-85$ & 10 & 72.8 & 9.04 \\
\hline Poisson's Ratio (v $)$ & $0.28-0.30$ & 3 & 0.29 & 0.01 \\
\hline $\begin{array}{l}\text { Young's Modulus } \\
\left(E_{D}\right)(\mathrm{GPa})\end{array}$ & $80-84$ & 3 & 81.7 & 2.08 \\
\hline Density $(\rho)$ (g/cm $\left.{ }^{3}\right)$ & $2.721-2.731$ & 3 & 2.726 & 0.0051 \\
\hline Porosity $(\phi)$ (vol\%) & $0.841-1.304$ & 17 & 1.035 & 0.152 \\
\hline
\end{tabular}

Table 2: Summary of the measured physical properties of Waipapa greywacke from this study.

\subsection{Tensile strength}

A standard deviation in tensile strength for the Waipapa greywacke samples indicates some variability (Table 2). Studies about the precision and reproducibility of tensile strength tests have been made by ASTM testing multiple specimens of different rocks (ASTM, D3967 - 08). Variability of tensile strengths measured here is not outside the norm for these types of experiments [Gale and Holder, 2008].

\subsection{Uniaxial compressive strength (UCS) and static elastic moduli}

For all UCS tests (Table 1), stress-strain curves show a slight concave-upwards trend at low loads, followed by a linear region showing no ductile behavior up to failure (Figure 4). No discernible yield point was observed before failure. Static Young's moduli range between 54 and 85 GPa and static Poisson's ratios range from 0.19 to 0.36 (Table 2). 


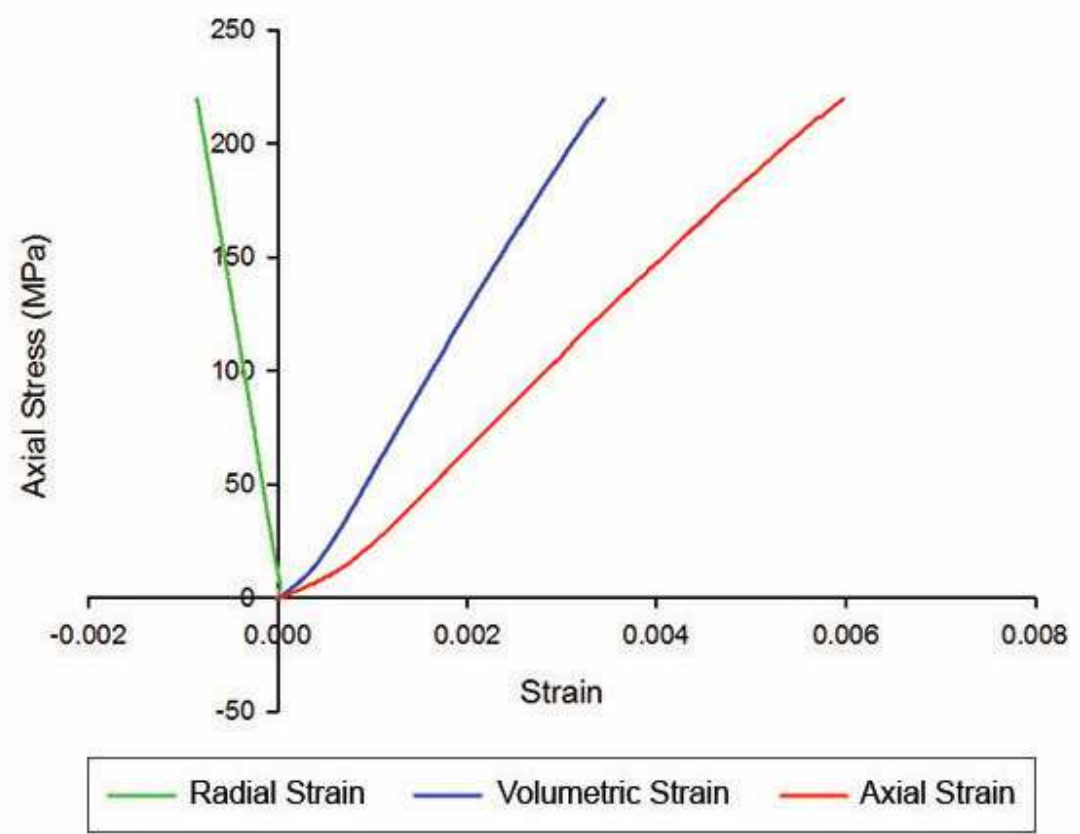

Figure 4: Stress-strain curves obtained from the uniaxial test of the Waipapa greywacke sample TTGW_11_2_2. These results are typical of the UCS tests in general.

\subsection{Triaxial compressive strength}

Permeability measurements (Table 1) performed prior to the start of the triaxial test provide an intact rock permeability of $1.65 \times 10^{-21} \mathrm{~m}^{2}$. Axial loading proceeded at a displacement rate of 0.1 microns/s, and the loading was stopped at regular intervals in order to obtain $\mathrm{P}$ and $\mathrm{S}$ wave velocity and permeability measurements (Figure 9). The axial displacement reported is corrected for the elastic distortion of the loading column which is $180 \mathrm{kN} / \mathrm{mm}$ for the apparatus.

The loading curve in Figure 5 shows a typical, initial concave upwards trend, then quasilinear loading, the slope of which provides a static Young's modulus of 55 GPa. No yield is observed as failure $(314 \mathrm{MPa})$ is approached, and the sample fails while still under quasi-linear loading. Reloading of the sample after failure occurs along a shallower gradient indicating the fractured sample is more compliant, and a residual strength of $\sim 120 \mathrm{MPa}$ is recorded. 
Throughout the triaxial test, as strain accumulates before failure is reached (Figure 5), the

permeability does not vary greatly. The small changes observed up to displacements of $\sim 0.42 \mathrm{~mm}$ are likely a result of measurement variability. Only immediately before failure is a dramatic increase in permeability seen, where the permeability increases by $\sim 4$ orders of magnitude. During this part of the loading history, the pore volume shows a decrease of $2.73 \mathrm{~mm}^{3}$ (Figure 6). Most of this decrease occurred during the initial loading of the sample.

Following failure and unloading of the sample, the permeability is much lower than seen at peak stress. Following residual strength yield, and a small amount of shearing along the shear fracture created during loading, the permeability increases slightly again.

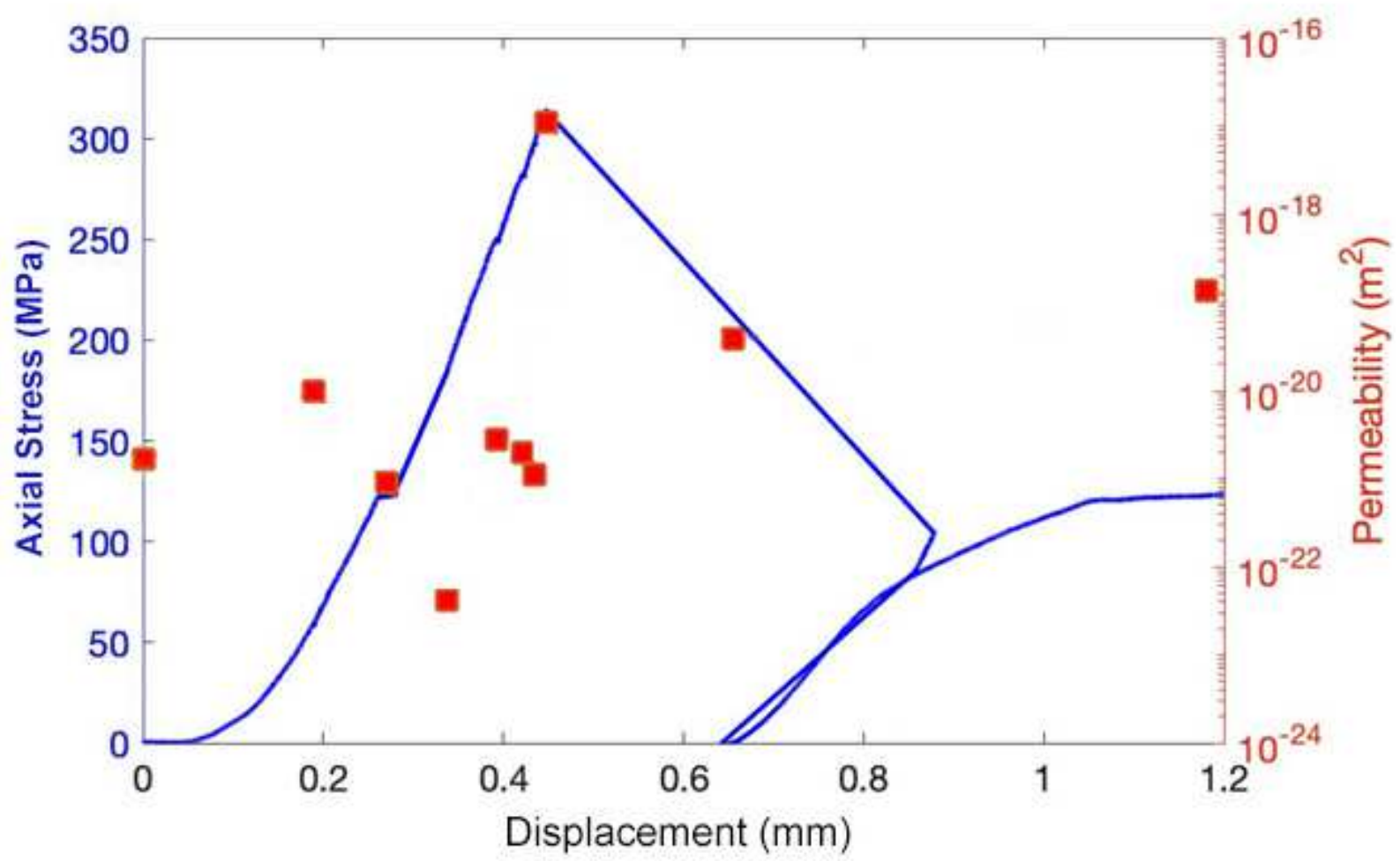

Figure 5: Results from the triaxial loading experiment. The blue line shows loading of the sample to failure, followed by unloading and reloading the sample with the shear fracture to residual failure. The red squares show the evolution of permeability during the loading history. 


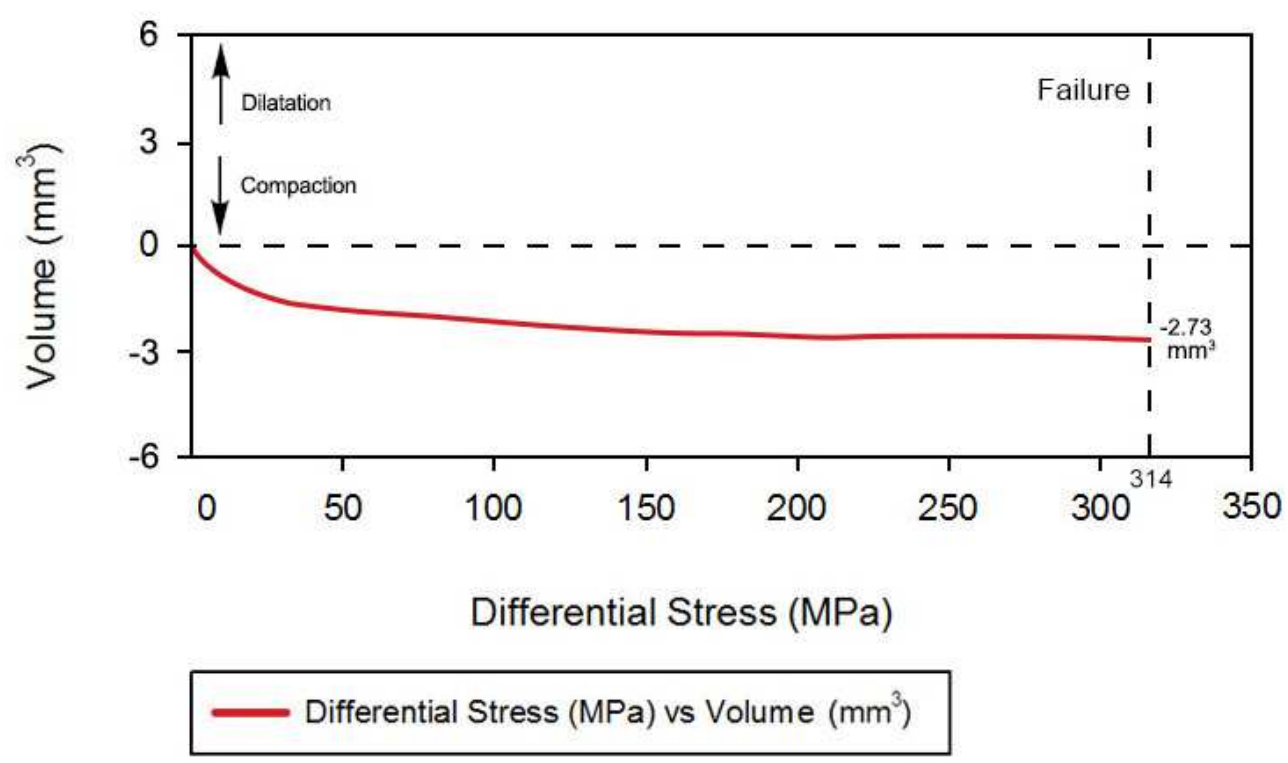

Figure 6: Pore volume change with increasing differential stress during the triaxial test.

\subsection{Scanning electron microscopy observations}

SEM observations (Table 1) of the shear fracture generated by the failure of the core during the triaxial test reveal it is filled with fragments of greywacke material (Figure 7a). The upper extremity of the fracture, where the sample comes into contact with the loading platen, widens and has a triangular shape, filled with large greywacke fragments $(\leq 0.675 \mathrm{~mm})$ set in a finer matrix ( $\leq 200 \mu \mathrm{m}$ sized cement grain). The typical aperture of the fracture is $<1 \mathrm{~mm}$. A network of subsidiary fractures develops close to both sides of the main rupture. This subsidiary fracture network is variable and includes both relatively wide fractures and clusters of narrower cracks. The subsidiary fractures have variable morphologies that are broadly parallel and sub-parallel to the main fracture, and parallel to the loading direction. Very few subsidiary brittle deformation features are observed at greater distance from the main rupture in the tested sample. 

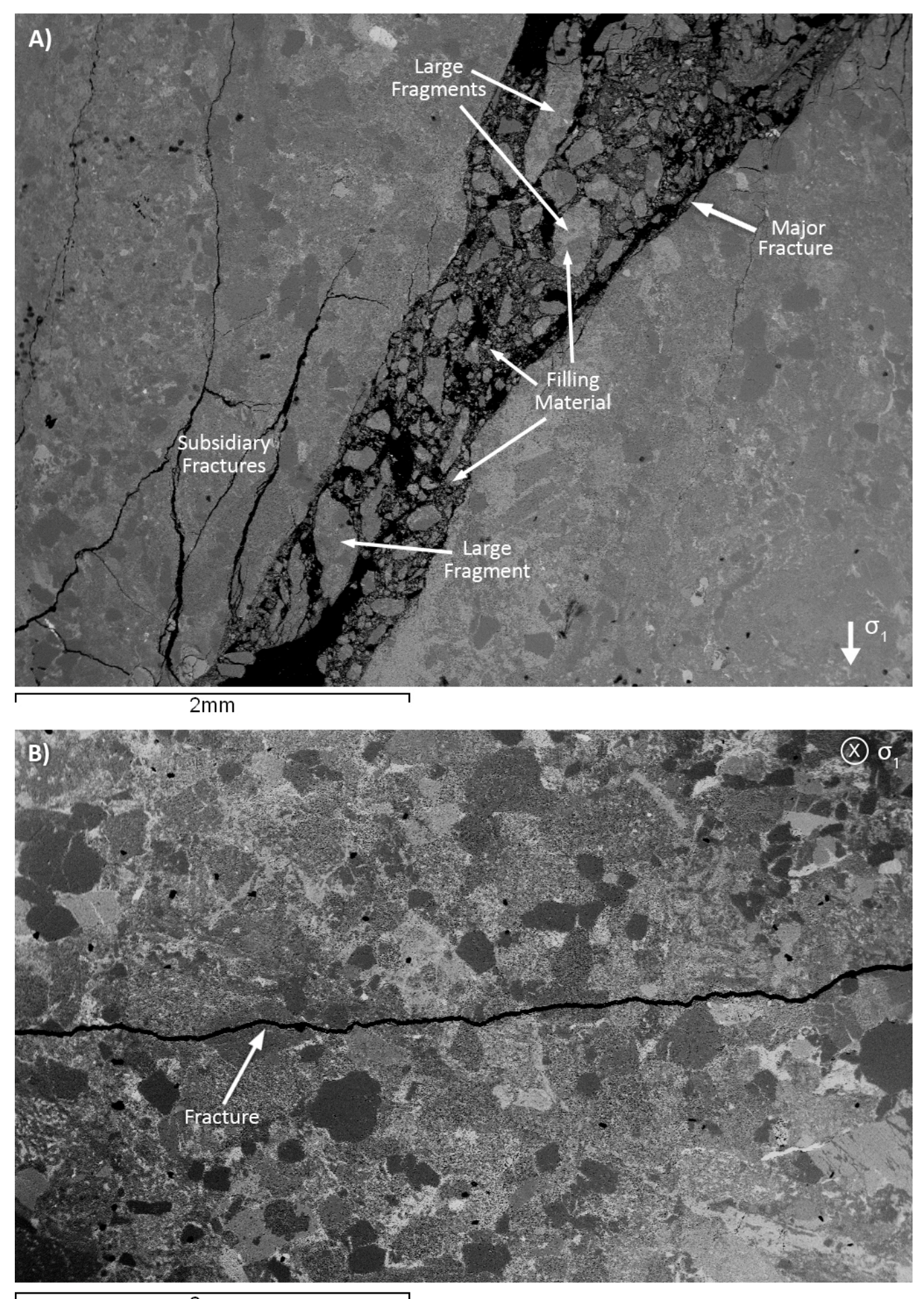

$2 \mathrm{~mm}$

350 Figure 7: A) SEM image of the greywacke sample TTGW_11_3 brought to failure in triaxial conditions. The deformed 351 sample was mounted in epoxy resin and cut and polished for imaging within the SEM. This image displays the shear 352 fracture and its filling material. A microfracture network is visible to the left side of the primary shear fracture. B) This 353 image is the result of an assembly of images that have been acquired using the SEM. It shows an induced fracture in a 354 greywacke disk (TTGW_11_3_17) using the Brazilian jig. 
The synthetically produced fractures from Brazilian loading (Figure 7b) show very little 357 comminution and, in contrast to the shear fracture (Figure 7a), few fragments contained within the 358 fracture. Fracture walls are a mixture of tortuous and straight, and rough and smooth, and the 359 fracture width is consistent $(\sim 25 \mu \mathrm{m})$. There is no development of a damage zone or subsidiary 360 fractures around the main fracture (Figure $7 \mathrm{~b}$ ). Similar post-failure conditions occurred for 361 TTGW_11_3_5 sample (Figure 10). and $S$-wave data were measured along the sample axis. From uniaxial tests, $V_{p}$ varies from 6,072 to $6,410 \mathrm{~m} / \mathrm{s}$ (Figure 8), and $V_{s}$ varies from 3,423 to 3,605 m/s. From the triaxial test, peak $V_{p}$ is 6,334 $\mathrm{m} / \mathrm{s}$ and peak $V_{s}$ is $3,647 \mathrm{~m} / \mathrm{s}$. Dynamic Poisson's ratio was in the range of $0.28-0.30$ and dynamic Young's modulus was in the range 80 to $84 \mathrm{GPa}$.

Figure 8 shows the trend of $V_{p}$ and $V_{s}$ for Waipapa greywacke during uniaxial testing. Data 371 shows an initial rapid increase in $V_{p}$ and $V_{s}$ as the differential stress is increased (Figure 8). After 372 that, $V_{p}$ and $V_{s}$ assume a sub-horizontal trend and show little changes up to the point of failure. In 373 detail, all the $V_{p}$ curves show fluctuation with a general increasing trend, while, for the $V_{s}$, in the 374 beginning the trend is upward, then it levels out until failure. Data from the triaxial test reveals a 375 similar trend between $V_{p}, V_{s}$, and axial stress (Figure 9). 

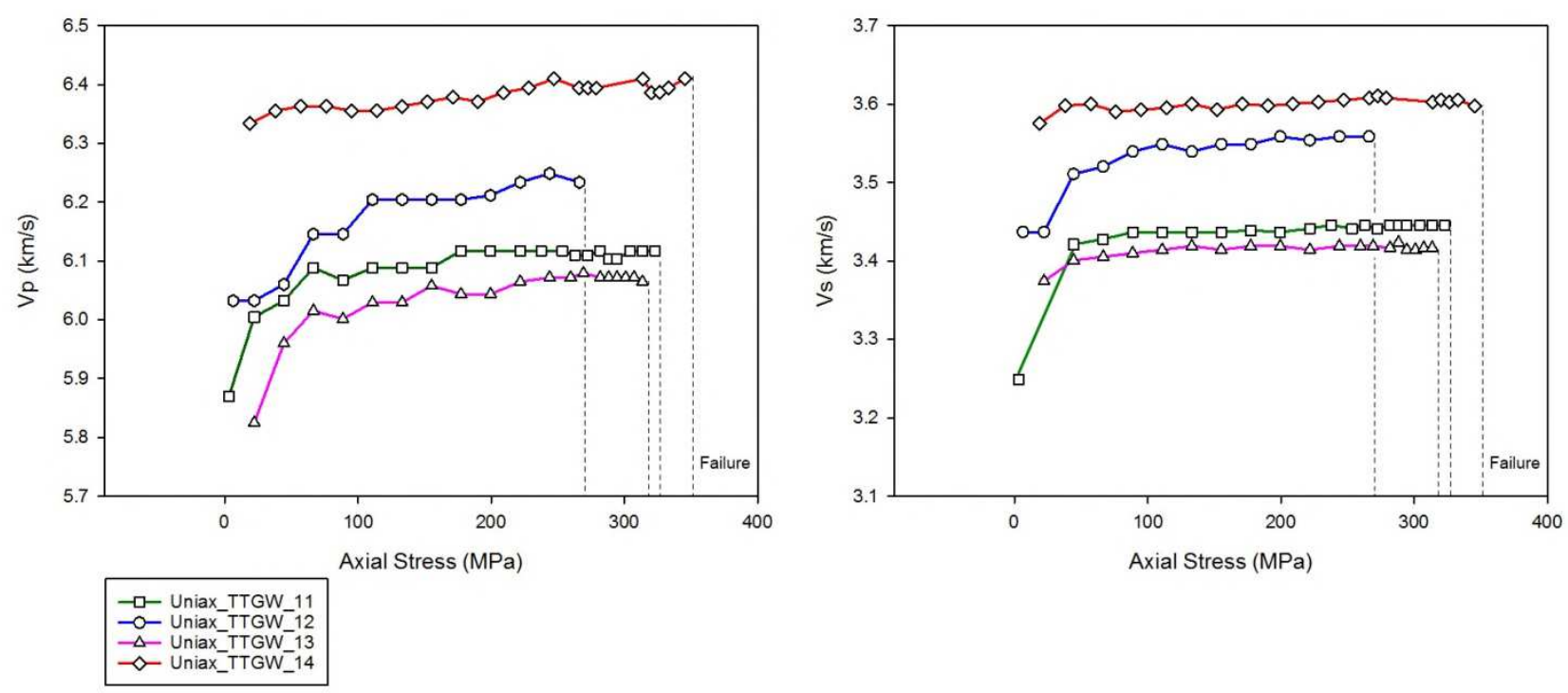

Figure 8: Seismic wave velocities $\left(V_{p}\right.$ and $\left.V_{s}\right)$ measured along the sample axis during uniaxial compressive tests.
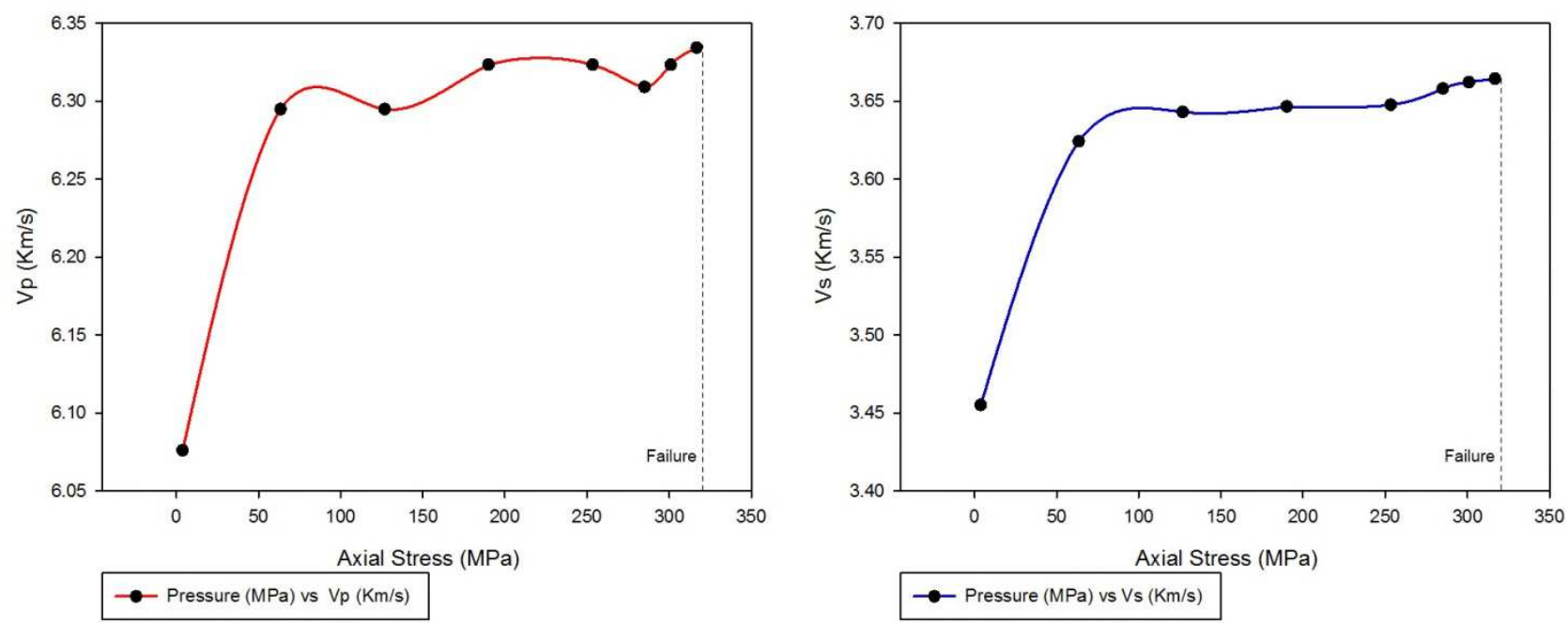

Figure 9: Seismic wave velocities $\left(V_{p}\right.$ and $\left.V_{s}\right)$ measured during triaxial compressive test.

\subsection{Single fracture permeability}

As confining pressure increased a monotonic decrease in permeability is observed for the

387 single, Mode I fracture in Waipapa greywacke (Figure 10). In both experiments, a similar trend in permeability response is observed, with permeability measurements (Table 1 ) between $10^{-16} \mathrm{~m}^{2}$ and $10^{-17} \mathrm{~m}^{2}$ made at $40 \mathrm{MPa}$ confining pressure, and permeability measurements of $\sim 10^{-19} \mathrm{~m}^{2}$ made at $150 \mathrm{MPa}$ confining pressures. At no point in the experiments did the fracture cease to allow the 
a)

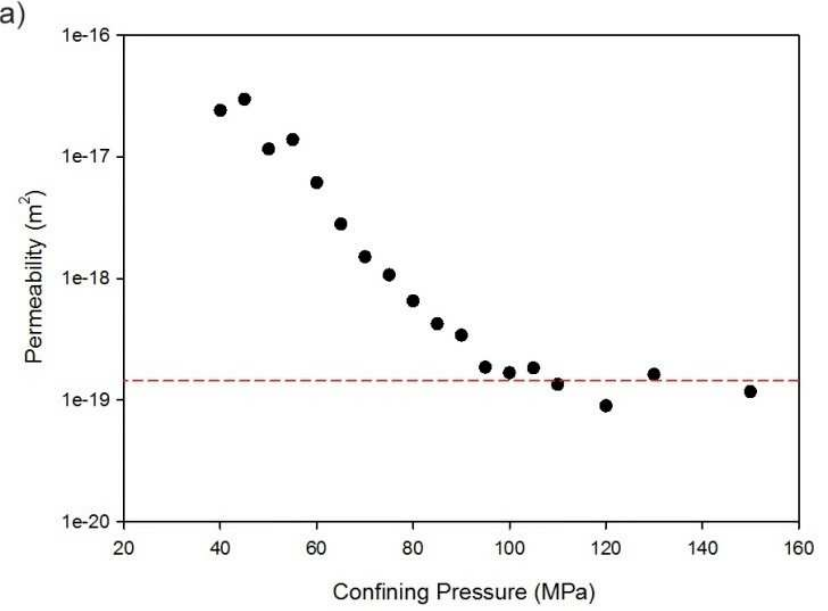

transmission of fluid along it. We saw that even with $150 \mathrm{MPa}$ confining pressure the permeability was still higher than measured for the intact samples (Figure 10).

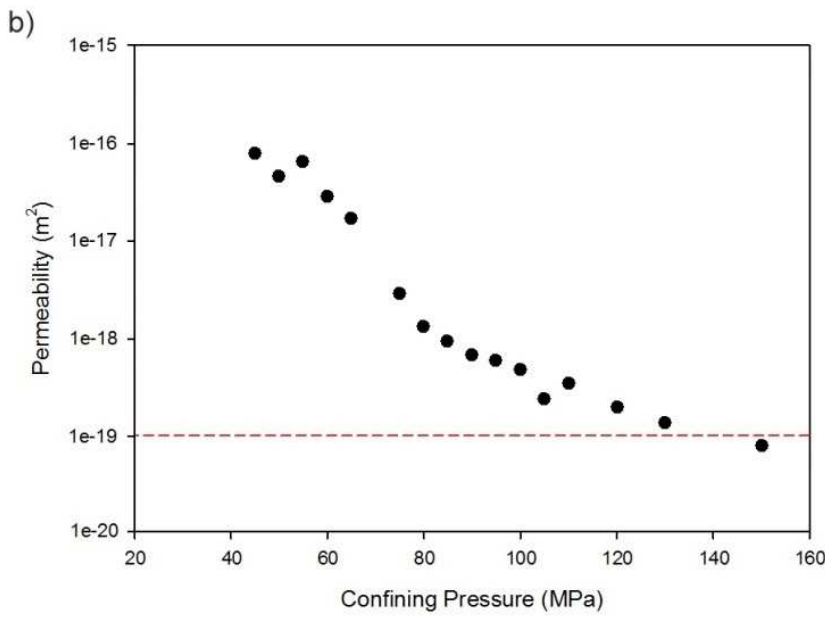

393 394 395 396 397 398

Figure 10: Graph of permeability against confining pressure through a single fracture (samples TTGW_11_3_5 (a) and TTGW_11_3_17 (b)). Red dashed line indicates where permeability becomes stable.

\section{DISCUSSION}

The physical properties of a lithology affect its ability to transmit fluid within it. The matrix permeability of a rock is the key factor influencing fluid flow in a rock type, which in turn is strongly influenced by porosity, pore connectivity and, for low porosity lithologies, microfractures. Beyond matrix permeability a lithology's ability to transmit fluid is dictated by the presence of structures [Evans et al., 2005], and the formation of structural permeability within a lithology is related to the mechanical properties of the rocks that constitute it. We discuss here our findings in the context of how they help understand fluid flow within Waipapa greywacke basement units.

\subsection{The role of microfractures in Waipapa greywacke mechanical strength}

The Waipapa greywacke mechanical strength reported here is high. As a comparison, the mechanical strength of the Waipapa greywackes (Table 3) is higher than that found in other 
lithologies reported as mechanically strong such as Westerly granite (UCS strength 200 MPa [Mitchell and Faulkner, 2008; Heap and Faulkner, 2008]), or the Rotokawa Andesite, another important geothermal reservoir rock in the TVZ (UCS strength of 60-211 MPa; [Siratovich et al., 2012, Siratovich et al., 2014]). Intact sedimentary rock strength is dependent on a variety of factors including the rock's diagenetic history, composition, maturity level (well-sorted, well-rounded), and the cumulative effect of the various geological processes experienced by them since formation such as metamorphism and deformation. Here we attempt to determine the controls on the strength of Waipapa greywacke.

In Waipapa greywacke porosity ranges from 0.841 to $1.304 \%$ (Table 3). These measurements of low porosity, coupled with the microstructural observations (Figure 3) illustrate the minimal primary porosity that exists within this lithology. The presence of microcracks in a low porosity lithology often contribute little to the overall porosity but can have an important impact on its mechanical strength, and thus the stresses at which it will experience brittle failure [Siratovich et al., 2014; Eberhardt et al., 1999; Faulkner et al., 2006; Lajtai, 1998]. Previous studies on low porosity crystalline rocks have shown that the presence of microfractures is evident by deviation from linear elastic behaviour at stress levels well below the failure stress, as well as an increase in volumetric strain [Mitchell and Faulkner, 2008; Zoback and Byerlee, 1975]. Both these observations lend support to the interpretation that, as loading progresses, existing microfractures start to propagate, leading to reduced compliance (related to deviation from linear elasticity) and volumetric strain increase.

There is strong evidence, in addition to the low porosity, that Waipapa greywacke has a low microcrack density. The loading curve (Figure 4) indicates little dilatancy from the volumetric strain curve and there is an appreciable lack of any yield point. This indicates that the formation of any microcrack network prior to failure is very limited, and contrasts with other studies on low 
porosity rock [Mitchell and Faulkner, 2008; Eberhardt et al., 1999; Zoback and Byerlee, 1975].

Moreover, the direct dilatancy measurements made via volumometry during the triaxial test also indicate little or no dilatancy prior to failure.

Elastic wave velocities can be strongly attenuated by the presence of microcracks in crystalline rocks [Siratovich et al., 2014; Vinciguerra et al., 2005; Blake et al., 2012; Heap et al., 2014] such that microcracking can strongly reduce $V_{p}$ and $V_{s}$. The mechanical test results from the Waipapa greywackes show, at the beginning of both the UCS tests and the triaxial loading test, minimal and, importantly, show no appreciable decrease immediately before failure that might indicate the development of a microcrack network (Figure 4; Figure 8). is heavily fractured in-situ. It may be that brittle damage is very localized around macrofractures, as we observed in our failed sample from our triaxial deformation experiment here (Figure 7). Reloading of the failed sample shows a much shallower gradient than initial (pre-failure) loading, indicating that the Young's modulus has appreciably decreased and the fractured sample is much more compliant, consistent with the presence of a larger population of microcracks, particularly in the near vicinity of the microfracture.

\begin{tabular}{|c|c|c|c|c|c|c|}
\hline Property & $\begin{array}{c}\text { TTGW } \\
\text { (this study) }\end{array}$ & $\begin{array}{c}\text { \# of } \\
\text { Tests }\end{array}$ & WAGW & $\begin{array}{c}\text { \# of } \\
\text { Tests }\end{array}$ & $\begin{array}{c}\text { Rotokawa } \\
\text { Andesite }\end{array}$ & $\begin{array}{c}\text { \# of } \\
\text { Tests }\end{array}$ \\
\hline $\begin{array}{c}\text { Tensile Strength } \\
\text { (MPa) }\end{array}$ & $14.4-32.42$ & 10 & $20.3-35.7$ & 8 & $9.99-24.13$ & 12 \\
\hline UCS (MPa) & $205-384$ & 10 & $301-310$ & 2 & $60-211$ & 22 \\
\hline Poisson's Ratio (v) & $0.19-0.54$ & 10 & $0.28-0.29$ & 2 & $0.09-0.34$ & 22 \\
\hline
\end{tabular}


458

459

460

461

462

463

464

465

466

467

468

469

470

\begin{tabular}{|c|c|c|c|c|c|c|}
\hline $\begin{array}{c}\text { Young's Modulus } \\
(E)(\mathrm{GPa})\end{array}$ & $54-85$ & 10 & $65-70$ & 2 & $20-44$ & 22 \\
\hline $\begin{array}{c}\text { Poisson's Ratio } \\
\left(v_{d}\right)\end{array}$ & $0.28-0.30$ & 3 & - & - & $0.13-0.23$ & 22 \\
\hline $\begin{array}{c}\text { Young's Modulus } \\
\left(E_{d}\right)(\mathrm{GPa})\end{array}$ & $80-84$ & 3 & - & - & $25-46$ & 22 \\
\hline Density $(\rho)\left(\mathrm{g} / \mathrm{cm}^{3}\right)$ & 2.727 & 3 & 2.71 & 2 & 2.49 & 22 \\
\hline Porosity $(\phi)($ vol\%) & 1.035 & 17 & $\sim 2$ & 2 & 8.44 & 22 \\
\hline
\end{tabular}

Table 3: A comparison of the physical and elastic properties values for Waipapa greywacke samples $(\mathrm{TTGW}=$ Taotaorao Quarry; WAGW = Waotu Quarry) measured in this study [this study; McNamara et al., 2014] and Torlesse greywacke [this study (porosity); McNamara et al., 2014, Stewart, 2007], Rototawa andesite [Siratovich et al., 2012, Siratovich et al., 2014]. Mean values are reported for density and porosity. Dynamic properties are identified in this table with the subscript " $d "\left(E_{d}\right.$ and $\left.v_{d}\right)$.

\subsection{Waipapa greywacke permeability}

The arguments presented above for the low microfracture density of the Waipapa greywacke have significant implications for the matrix permeability of this rock. The microcrack density does not have a great influence on the porosity, but the permeability is strongly affected by the presence of microcracks [Costa, 2006; Chaki, 2008], though this is strongly dependent on effective stress levels and whether the rock undergoes brittle failure or not [Faulkner and Armitage, 2013; Zoback and Byerlee, 1975]. In this study, Waipapa greywacke displayed no sign of significant dilatancy during deformation experiments (Figs. 4-6), and a lack of decrease in $V_{p}$ and $V_{s}$ before failure in both uniaxial and triaxial tests. This is complemented by the absence of enhanced permeability observed during loading to failure in the triaxial deformation experiment (Figure 5). In terms of macrofracture generation within intact Waipapa greywacke, it appears that dilation of axially aligned microcracks and their subsequent coalescence plays a limited role in the brittle deformation and permeability development of this lithology, occurring at stress levels commensurate with those at failure. 
The results given in Table 2 are comparable to previous measurements on porosity of

Waipapa greywacke [Mielke et al., 2016], and porosity and permeability measurements made under the same conditions for Torlesse greywacke $\left(\sim 1.6 \%, \sim 4.824 \times 10^{-22} \mathrm{~m}^{2}\right.$; [McNamara et al., 2014]), which also hosts geothermal reservoirs [Milicich et al., 2016]. These greywacke lithologies display the lowest porosity and permeability values measured to date across a range of New Zealand geothermal lithologies. For comparison, Rotokawa andesite has permeability values four to five orders of magnitude greater than the greywacke units $\left(\sim 10^{-17} \mathrm{~m}^{2}\right)$ [Siratovich et al., 2014], and greater porosity values (Table 3), while lithologies from the Tahorakuri Formation, Matahina ignimbrite, Te Teko Formation, Tahuna Formation, and a range of TVZ andesite, dacite, and rhyolite lavas all have higher average porosity values [Mielke et al., 2016, Wyering et al., 2014].

As discussed, inherent microcrack density, porosity, and permeability are linked such that increased microcrack density, increases porosity, which in turn can increase permeability [Costa, 2006; Chaki et al., 2008], though this is strongly dependant on effective stress levels (Figure 5) and whether the rock undergoes brittle failure or not [Zoback and Byerlee, 1975]. The low porosity range reported here for Waipapa greywacke suggests a low density of inherent microstructures in this lithology, and those that are present are minimally connected. This is supported by the low permeability measurements $\left(1.65 \times 10^{-21} \mathrm{~m}^{2}\right)$, the low reduction in volume observed under triaxial deformation experiments, and SEM images reported in this study.

It has been well demonstrated that faults and fractures in brittle rock are produced by the interaction and fusion of many microcracks [Mitchell and Faulkner, 2008; Lockner et al., 1991; Lockner et al., 1992b; Reches and Lockner, 1994; Healy et al., 2006]. As a result, when differential stress is applied to an intact rock sample, microfracture damage increases as the rock approaches failure, and the resultant increasing dilatancy will have direct impacts on both porosity and permeability. For example, permeability increases in Westerly Granite as it is triaxially deformed are recorded as the granite failure strength is approached due to increasing development of microcracks, which then increases further as stress is relaxed allowing more connectivity between 
variable oriented microcracks in the rock [Mitchell and Faulkner, 2008; Zoback and Byerlee, 1975]. In this study, Waipapa greywacke displayed no sign of significant dilatancy during deformation experiments, both uniaxial and triaxial (Figs. 4-6), similar to results reported in McNamara et al., (2014). This lack of dilatancy is supported by the lack of decrease in $V_{p}$ and $V_{s}$ before failure in both uniaxial and triaxial tests, and a lack of increased permeability observed during loading in the triaxial deformation experiment (Figure 5). In terms of macrofracture generation within intact Waipapa greywacke, it appears that dilation of axially aligned microcracks and their subsequent coalescence plays either no role in brittle deformation of this lithology, or that it happens within a fast timeframe not captured by our experimental work here. Concerning contributions pre-failure deformation makes to Waipapa greywacke permeability, we conclude this is likely to be small, though suggest future experiments of this nature be performed at higher resolution along the stressstrain path. Our results suggest that Waipapa permeability is dominated by macrostructures, as no permeability is witnessed to be generated by dilatancy effects from deformation in this lithology, agreeing with similar conclusions made elsewhere [McNamara et al., 2014].

Passelègue et al. (2018) demonstrate that permeability anisotropy is caused when the intact rock is loaded to macroscopic failure though the rock being deformed is essentially isotropic, indicating that permeability anisotropy begins to evolve only after a lithology is deformed, and that anisotropy will be aligned with respect to the stress state that generated the fractures. Considering the low permeability of intact Waipapa greywacke, permeability anisotropy is expected to be an important aspect of this lithology as a geothermal reservoir. Experimental data presented here confirms the introduction of permeability anisotropy within Waipapa greywacke. Rapid, large increases in permeability (around four orders of magnitude, from $10^{-21} \mathrm{~m}^{2}$ to $10^{-17} \mathrm{~m}^{2}$ ) at the point of brittle failure are noted from the triaxial compression experiment (Figure 5) and the single fracture permeability tests (Figure 10). Thus, permeability dramatically increases in Waipapa greywacke rocks as a result of brittle deformation, implying an anisotropic permeability will develop, oriented with respect to a given stress field. 
Defining the orientation of such permeable anisotropy in Waipapa greywacke not simple given the complex nature of the tectonics associated with this lithology in geothermal regions [McNamara et al., 2019]. Within the TVZ the Waipapa greywacke is subject to NW-SE directed extension, with local variations [McNamara et al., 2019]. Under contemporary tectonic conditions, fractures generated in Waipapa greywacke will predominantly align to this stress state (striking NESW, parallel to $\sigma_{2}$ ), thus defining the permeability anisotropy. However, the Waipapa greywacke has undergone deformation prior to TVZ rifting resulting in previous brittle deformation in a range of orientations [Roland and Sibson, 2004]. We suggest that lateral permeability anisotropy in Waipapa greywacke will be aligned to the strike of the TVZ rift (NE-SW), in which both brittle structures formed during rifting, and brittle structures formed pre-rifting, but preferentially aligned for slip in the current stress field, control geothermal fluid flow. Indeed, a dominant NE-SW fracture strike orientation is shown within fluid flow zones in geothermal wells drilled into Torlesse greywacke basement at the Kawerau Geothermal Field [Wallis et al., 2004], establishing these fracture patterns do exist in greywacke basement type lithologies in the TVZ. Implications of our findings for geothermal fluid flow in the Waipapa greywacke reservoir Ngawha Geothermal Field are more difficult to determine due to a lack of direct structural or stress information from this location [Mongillo, 1985]. Reported structures have E-W, and NE-SW strike orientations and are associated with NW-SE directed extension in the region [Bayrante and Spörli, 1989]. Assuming this structure-stress arrangement, we can infer from out experimental results that a macrofracture related permeability anisotropy aligned NE-SW would form in the Waipapa basement of the Ngawha Geothermal Field.

In a geothermal reservoir where permeability is controlled by macrostructures, such as those in Waipapa greywacke, the ability for brittle structures to maintain fluid flow is important to the resource longevity and sustainability. This study examined the effect of single macrofracture behavior on the permeability of Waipapa greywacke. Macrofracture closure pressures of synthetically generated fractures in Waipapa greywacke falls between 95 to $112 \mathrm{MPa}$. At these 
closure pressures, fluid flow across the fracture was observed to continue, developing a stable permeability around $10^{-19} \mathrm{~m}^{2}$ for confining pressures between 95 and $150 \mathrm{MPa}$ (Figure 10). Thus, even at closure, macrofractures in the Waipapa greywacke provide continued permeability ( 2 orders of magnitude higher than intact greywacke permeability). Permeability measurements on fractured greywacke under triaxial conditions also support persistent permeability in greywacke fractures post initial failure (Figure 5). Similar large increases in permeability from inducing a single fracture are reported from dense volcanic rocks in geothermal regions [Lamur et al., 2017]. Persistent permeability in Waipapa greywacke fractures under closure pressures may be facilitated by incomplete fracture closure due to the presence of fragments inside the fractures propping it open, asperity generation, permeability via secondary brittle damage generated around the main brittle fracture (Figure 10). Our observations suggest all three possibilities may contribute in some way. A size range of wall rock fragments are observed within the triaxial fracture experiment, some of which are likely more than significant to prop open a newly generated fractures and facilitate ongoing fluid flow within it. The longevity of this propping is uncertain, as over time with ongoing fracture slip, these fragments may be constantly reduced in size and maintain less open space. With enough time and comminution of facture fill material, combined with fluid-rock interaction, gouge may be generated and potentially seal the fracture completely to fluid flow. Asperity generation in fractures tested here will certainly play a role in ongoing fracture permeability after closure pressures are reached, as morphologically different fracture walls are observed in fractures generated in both triaxial and tensile tests. As with grain propping, there is a time limit to the ability for asperity to maintain fluid flow in a fracture as consistent slip will eventually grind these asperities down. The exact contribution secondary brittle damage makes to observed greywacke permeability is unknown, which makes it difficult to address in terms of their contribution to permeability under closure pressures. Given these secondary structures generated under the same experimental conditions as the primary brittle failure it is reasonable to assume they would behave 
similarly to the main fracture, though given their more varied orientation with respect to $\sigma_{1}$, and the high level of intersection observed this is questionable and requires further study.

It should be noted that the results from the measurements on the single fracture are represented in terms of permeability to allow direct comparison with the permeability of the intact rock. Strictly, reporting permeability for fracture flow is not correct, as the calculation assumes that fluid flow occurs over the crossectional area of the specimen, whereas for rocks with a low matrix permeability, fluid will predominantly flow through the fracture. Consequently, the 'permeability' becomes scale dependent [Heap and Kennedy, 2016]. This can be illustrated by considering that if the sample diameter were doubled, the flow would also double, as the length of the fracture has increased by a factor of two. However, the crossectional area used in the permeability calculation would quadruple and the permeability would appear to half for the larger specimen. Hydraulic transmissivity, the product of the fracture permeability and its thickness, is a better way to represent the flow properties of fractures. This parameter can be derived from the pulse transient measurements we made using the methodology described by Rutter and Mecklenburgh (2018).

In summary, intrinsic microfracture density in Waipapa greywacke is low, and the development, coalescence, and growth of the microfracture network before failure is minimal. Consequently, microfractures do not play a key role in the formation of permeable structures within the Waipapa greywacke lithology. Macrofractures demonstrably increase permeability in Waipapa greywacke, contribute to long-lived permeability post-failure, and the permeability they develop within this lithology is anisotropic, and so permeability vectors in the greywacke units will be related to the local and regional stress conditions. 


\section{CONCLUSIONS}

Our experiments indicate a high mechanical strength for intact Waipapa greywacke quantify the fluid flow properties of this basement lithology needed for accurate modelling.

lithology that is partly due to a low density of inherent microcracks. This lack of microcracks contributes to the low intrinsic porosity and permeability of intact Waipapa greywacke. Our experiments confirm that the Waipapa greywacke lithology will only support fluid flow via the generation of macrostructures. Furthermore, these macrofractures maintain a level of permeability after stress conditions relax (fracture closure). Brittle fractures generated in Waipapa greywacke thus remain important permeable components in this lithology for an undetermined length of time after their formation. Such macrofracture controlled permeability is inherently anisotropic and as such the directionality of fluid transmission in the Waipapa greywacke will be strongly controlled by the arrangement of the local tectonic stress field as this controls orientation of microfracture development. Given that structures impart strong permeability anisotropy to Waipapa basement, any fluid flow modeling of geothermal systems within such geological units should account for this.

Further studies on Waipapa greywacke mechanical strength that simulate deeper crustal levels, and flow experiments through single macrostructures under such conditions are required to better
624

625

626

627

628 629 630

631

632 25 28

\section{6}


Adams CJ, Mortimer N, Campbell HJ, Griffin WL. Age and isotropic characterisation of 636 metasedimentary rocks from the Torlesse Supergroup and Waipapa Group in the central North Island, New Zealand. New Zealand Journal of Geology and Geophysics. 2009;52:149-170. https://doi.org/10.1080/00288300909509883

Bayrante LF, Spörli KB. Structural observations in the autochthon and allochthon at Ngawha 641 geothermal field, New Zealand. Geology of Northland: Accretion, allochthon and arcs at the edge of the New Zealand micro-continent. Royal Society of New Zealand Bulletin. 1989;26:106-114.

Beetham RD, Watters WA. Geology of Torlesse and Waipapa terrane basement rocks encountered during the Tongariro power development project, North Island, New Zealand. New Zealand journal of geology and geophysics. 1985;28:575-594. https://doi.org/10.1080/00288306.1985.10422534

Begg JG, Mazengarb C. Part Q27, scale 1:50,000, Lower Hutt: Institute of Geological \& Nuclear Sciences. Institute of Geological \& Nuclear Sciences geological map 22. 128 p. +1 fold. 653 654 655 656 657 658 659 660 661 662 Map. 1996.

Bibby H, Caldwell T, Davey F, Webb T. Geophysical evidence on the structure of the Taupo Volcanic Zone and its hydrothermal circulation. Journal of Volcanology and Geothermal Research. 1995;68:29-58. https://doi.org/10.1016/0377-0273(95)00007-H

Bignall G. Taupo Volcanic Zone deep geothermal drilling project. Proceedings Hotter and Deeper Exploration Science Workshop, Taupo, New Zealand. 2011. https://www.geothermal-energy.org/pdf/IGAstandard/NZGW/2011/K2.pdf (2011). Accessed 31 October 2021.

Bignall G, Rae A, Rosenberg M. Rationale for targeting fault versus formation-hosted permeability in high-temperature geothermal systems of the Taupo Volcanic Zone, New Zealand. Proceedings, World Geothermal Congress, Bali, Indonesia. 2010. https://www.geothermal-energy.org/pdf/IGAstandard/WGC/2010/1148.pdf (2010). Accessed 31 October 2021. 
Blake OO, Faulkner DR, Rietbrock A. The effect of varying damage history in crystalline rocks on the $\mathrm{P}$ and $\mathrm{S}$ wave velocity under hydrostatic confining pressure. Pure Applied Geophysics. 2012;170:493-505. https://doi.org/10.1617/s11527-016-0892-7

Brace WF, Walsh JB, Frangos WT. Permeability of granite under high pressure. Journal of Geophysical Research. 1968;73:2225-2236. https://doi.org/10.1029/JB073i006p02225

Brathwaite RL, Wood CP, Rosenberg MD, Faure K. Porosity and permeability in the basement rocks at the Kawerau and Ohaaki geothermal fields, New Zealand. IN: Soengkono S, Browne PRL. Proceedings, 24th New Zealand Geothermal Workshop, University of Auckland. 2002;24:49-54.

https://www.geothermal-energy.org/pdf/IGAstandard/NZGW/2002/Brathwaite.pdf (2002). Accessed 31 October 2021.

Browne PRL. Joint channels in reservoir rocks of the Ngawha geothermal field, Northland. Proceeding, 2nd New Zealand Geothermal Workshop, University of Auckland. 1980;81-84. https://www.geothermal-energy.org/pdf/IGAstandard/NZGW/1980/Browne.pdf (1980). Accessed 31 October 2021.

Cant JL, Siratovich PA, Cole JW, Villeneuve MC, Kennedy BM. Matrix permeability of reservoir rocks, Ngatamariki geothermal field, Taupo Volcanic Zone, New Zealand. Geothermal Energy. 2018;6. http://dx.doi.org/10.26021/8877

Carey B, Dunstall M, McClintock S, White B, Bignall G, Luketina K, Robson B, Zarrouk S, Seyward A. New Zealand country update. World Geothermal Congress, Melbourne. 2015.

Chaki S, Takarli M, Agbodjan WP. Influence of thermal damage on physical properties of a granite rock: porosity, permeability and ultrasonic wave evolutions. Construction and Building Materials. 2008;22:1456-1461. https://doi.org/10.1016/j.conbuildmat.2007.04.002

Cole JW, Spinks KD. Caldera volcanism and rift structure in the Taupo Volcanic Zone, New Zealand. Geological Society, London, Special Publications. 2009;327:9-29.

http://dx.doi.org/10.1144/SP327.2 
Costa A. Permeability-porosity relationship: A reexamination of the Kozeny-Carman equation based on a fractal pore-space geometry assumption. Geophysical research letters. 2006. https://doi.org/10.1029/2005GL025134

Cox ME, Browne PRL. Hydrothermal alteration mineralogy as an indicator of hydrology at the Ngawha Geothermal Field, New Zealand. Geothermics. 1998;27:259-270. https://doi.org/10.1016/S0375-6505(97)10015-3

Di Pippo R. Geothermal power plants: principles, applications, case studies and environmental impact. Elsevier Ltd, 2nd edition, Oxford. 2008.

Eberhardt E, Stead D, Stimpson B. Quantifying progressive pre-peak brittle fracture damage in rock during uniaxial compression. International Journal of Rock Mechanics and Mining Sciences. 1999;36:361-380. https://doi.org/10.1016/S0148-9062(99)00019-4

Evans KF, Genter A, Sausse J. Permeability creation and damage due to massive fluid injections into granite at $3.5 \mathrm{~km}$ at Soultz: 1. Borehole observations. Journal of Geophysical Research e Solid Earth. 2005;110(B4). https://doi.org/10.1029/2004JB003168

Faulkner DR, Armitage PJ. The effect of tectonic environment on permeability development around faults and in the brittle crust. Earth and Planetary Science Letters. 2013;375:71-77. https://doi.org/10.1016/j.eps1.2013.05.006

Faulkner DR, Mitchell TM, Healy D, Heap MJ. Slip on "weak" faults by the rotation of regional stress in the fracture damage zone. Nature. 2006;444:922-925. https://doi.org/10.1038/nature05353

Gale JFW, Holder J. Natural fractures in the Barnett Shale: Constraints on spatial organization and tensile strength with implications for hydraulic fracture treatment in Shale-Gas reservoirs. In: 42nd U.S. Rock Mechanics Symposium \& 2nd U.S.-Canada Rock Mechanics Symposium: ARMA. 2008;08-96.

Grant MA, Bixley PF. Geothermal Reservoir Engineering, 2nd edition, Academic Press, Burlington, USA. 2011. doi: 10.1016/C2010-0-64792-4 
738 Gupta H, Sukanta R. An alternative resource for the 21st Century. Geothermal Energy, 1st edition, 739 Elsevier Science. 2006.

740

Lockner DA, Byerlee JD, Kuksenko V, Ponomarev A, Sidorin A. Quasi-static fault growth and shear fracture energy in granite, Nature. 1991;350:39-42. https://doi.org/10.1038/350039a0

Healy D, Jones RR, Holdsworth RE. Three-dimensional brittle shear fracturing by tensile crack interaction. Nature. 2006;439:64-67. https://doi.org/10.1038/nature04346

Heap MJ, Faulkner DR. Quantifying the evolution of static elastic properties as crystalline rock approaches failure. International Journal of Rock Mechanics and Mining Sciences. 2008;45:564-573.

Heap MJ, Kennedy B. Exploring the scale-dependent permeability of fractured andesite. Earth and Planetary Science Letters. 2016;447:139-150. https://doi.org/10.1016/j.eps1.2016.05.004

Heap MJ, Lavallée Y, Petrakova L, Baud P, Reuschlé T, Varley NR, Dingwell DB. Microstructural controls on the physical and mechanical properties of edifice-forming andesites at Volcán de Colima, Mexico. Journal of Geophysical Research, Solid Earth. 2014;119:2925-2963. https://doi.org/10.1002/2013JB010521

Kuttruff H. Ultrasonics fundamentals and applications. Elsevier, Science \& Technology, New York. 1991.

Lajtai EZ. Microscopic fracture processes in a granite. Rock Mechanics and Rock Engineering. 1998;31:237-250. https://doi.org/10.1007/s006030050023

Lamur A, Kendrick JE, Eggertsson GH, Wall RJ, Ashworth JD, Lavallée Y. The permeability of fractured rocks in pressurised volcanic and geothermal systems. Scientific reports. 2017;7:61-73. https://doi.org/10.1038/s41598-017-05460-4 
Lockner DA, Byerlee JD, Kuksenko V, Ponomarev A, A, Sidrin. Observations of quasi-static fault growth from acoustic emissions, Fault Mechanics and Transport Properties of Rocks, edited by Evans B, and Wong TF. Academic, San Diego, California. 1992b:3-31.

Mayer W. Petrology of the Waipapa Group, near Auckland, New Zealand. New Zealand Journal of Geology and Geophysics. 1968;12:412-435. https://doi.org/10.1080/00288306.1969.10420291

McGuinness MJ. Recent interference tests at Ngawha and Ohaaki. Proceedings, 6th New Zealand Geothermal Workshop. 1984;169-174. https://pangea.stanford.edu/ERE/pdf/IGAstandard/NZGW/1984/McGuinness.pdf (1984).

McNamara DD, Faulkner DR, McCarney E. Rock Properties of Greywacke Basement Hosting Geothermal Reservoirs, New Zealand, preliminary results. Proceedings, 39th Workshop Geothermal Reservoir Engineering, Stanford University, California. 2014;10-21. doi:10.13140/RG.2.1.1304.2160

McNamara DD, Massiot C. Geothermal structural geology in New Zealand: Innovative Characterisation and micro-analytical techniques. Proceedings, 38th New Zealand Geothermal Workshop, Auckland, New Zealand. 2016. https://www.geothermal-energy.org/pdf/IGAstandard/NZGW/2016/Keynote_McNamara.pdf (2016). Accessed 31 October 2021.

McNamara DD, Milicich SD, Massiot C, Villamor P, McLean K, Sépulveda F, Ries WF. Tectonic controls on Taupo Volcanic Zone geothermal expression: Insights from Te Mihi, Wairakei Geothermal Field. Tectonics. 2019. https://doi.org/10.1029/2018TC005296

McNamara DD, Sewell S, Buscarlet E, Wallis IC. A review of the Rotokawa Geothermal Field, New Zealand. Geothermics. 2016;59:281-293. https://doi.org/10.1016/j.geothermics.2015.07.007

Mielke P, Weinert S, Bignall G, Sass I. Thermo-physical rock properties of greywacke basement rock and intrusive lavas from the Taupo Volcanic Zone, New Zealand. Journal of Volcanology and Geothermal Research. 2016;324:179-189. 
https://doi.org/10.1016/j.jvolgeores.2016.06.002

Milicich SD, Clark JP, Wong C, Askari M. A review of the Kawerau geothermal field. New Zealand. Geothermics. 2016;59:252-265. https://doi.org/10.1016/j.jvolgeores.2018.01.012

Milicich SD, Wilson CJN, Bignall G, Pezaro B, Charlier BLA, Wooden JL, Ireland TR. U-Pb dating of zircon in hydrothermally altered rocks of the Kawerau Geothermal Field, Taupo Volcanic Zone, New Zealand. Journal of Volcanology and Geothermal Research. 2013a;253:97-113. https://doi.org/10.1016/j.jvolgeores.2012.12.016

Mitchell TM, Faulkner DR. Experimental measurements of permeability evolution during triaxial compression of initially intact crystalline rocks and implications for fluid flow in fault zones. Journal of Geophysical Research. 2008;113. https://doi.org/10.1029/2008JB005588

Mongillo MA. The Ngawha geothermal field: new and updated scientific investigations. Geothermal Coordination Group, Department of Scientific and Industrial Research. 1985.

Mroczek EK, Milicich SD, Bixley PF, Sepulveda F, Bertrand EA, Soengkono S, Rae AJ. Ohaaki geothermal system: Refinement of a conceptual reservoir model. Geothermics. 2016;59:311324. https://doi.org/10.1016/j.geothermics.2015.09.002

Nara Y, Meredith PG, Yoneda T, Kaneko K. Influence of macro-fractures and micro-fractures on permeability and elastic wave velocities in basalt at elevated pressure. Tectonophysics. 2011;503:52-59. https://doi.org/10.1016/j.tecto.2010.09.027

Passelègue FX, Pimienta L, Faulkner DR, Schubnel A, Fortin JN, Guéguen Y. Development and recovery of stress-induced elastic anisotropy during cyclic loading experiment on Westerley granite. Geophysical Research Letters. 2018;45:8156-816.

https://doi.org/10.1029/2018GL078434

Paterson M, Wong T. Experimental rock deformation - The brittle field. Springer-Verlag. 2005;1213. 
Reches Z, Lockner DA. Nucleation and growth of faults in brittle rocks. Journal of Geophysics Research. 1994;99:159-173. https://doi.org/10.1029/94JB00115

Richards L, Read S. New Zealand greywacke characteristics and influences on rock mass behavior. Proceedings, 11th Congress of the International Society of Rock Mechanics: the second half century of rock mechanics. 2007;359-364.

Rowland JV, Sibson RH. Structural controls on hydrothermal flow in a segmented rift system, Taupo Volcanic Zone, New Zealand. Geofluids. 2004;4:259-283. https://doi.org/10.1111/j.1468-8123.2004.00091.x

Rutter EH, Mecklenburgh J. Influence of normal and shear stress on the hydraulic transmissivity of thin cracks in a tight quartz sandstone, a granite, and a shale. Geophysical Research: Solid Earth. 2018;123. https://doi.org/10.1002/2017JB014858

Sheppard DS. Fluid chemistry of the Waimangu geothermal system. Geothermics. 1986;15:309328. https://doi.org/10.1016/0375-6505(86)90107-0

Sherburn S, Bannister SC, Bibby HM. Seismic velocity structure of the central Taupo Volcanic Zone, New Zealand, from local earthquake tomography. Journal of Volcanology and Geothermal Research. 2003;122:69-88. https://doi.org/10.1016/S0377-0273(02)00470-5

Siratovich PA, Davidson J, Villeneuve M, Graveley D, Kennedy B, Cole J, Wyering L, Price L. Physical and mechanical properties of the Rotokawa Andesite from production wells RK 27_L2, RK 28 and RK 30. Proceedings, New Zealand Geothermal Workshop, University of Auckland, New Zealand. 2012. https://www.geothermal-energy.org/pdf/IGAstandard/NZGW/2012/46654final00022.pdf

Siratovich PA, Heap MJ, Villeneuve MC, Cole JW, Reuschlé T. Physical property relationships of the Rotokawa Andesite, a significant geothermal reservoir rock in the Taupo Volcanic Zone, New Zealand. Geothermal Energy. 2014;2:1-31. https://doi.org/10.1186/s40517-014-0010-4 
Siratovich PA, Von Aulock FW, Lavallée Y, Cole JW, Kennedy BM, Villeneuve MC. Thermoelastic properties of the Rotokawa Andesite: A geothermal reservoir constraint. Journal of Volcanology and Geothermal Research. 2015;301:1-13. http://dx.doi.org/10.1016/j.jvolgeores.2015.05.003.

Stewart S. Rock mass strength and deformability of unweathered closely jointed New Zealand greywacke, PhD Thesis, University of Canterbury, Christchurch, New Zealand. 2007. http://dx.doi.org/10.26021/3499

Sutherland R, Townend J, Toy V, Zimmer M. Extreme hydrothermal conditions at an active platebounding fault. Nature. 2017;546:137-140. https://doi.org/10.1038/nature22355

Vinciguerra S, Trovato C, Meredith PG, Benson PM. Relating seismic velocities, thermal cracking and permeability in Mt. Etna and Iceland basalts. International Journal of Rock Mechanics and Mining Sciences. 2005;42:900-910. https://doi.org/10.1016/j.ijrmms.2005.05.022

Wallis IC, Bardsley CJ, Powell TS, Rowland JV, O’Brien JM. A structural model for the Rotokawa Geothermal Field, New Zealand. Proceedings, 35th New Zealand Geothermal Workshop, Auckland University, New Zealand. 2013.

Wallis I, McNamara DD, Rowland J, Massiot C. The nature of fracture permeability in the greywacke basement at Kawerau Geothermal Field, New Zealand. In Proceedings, 37th Workshop on Geothermal Reservoir Engineering. 2012. doi:10.13140/RG.2.1.4875.9284

Wilson CJN, Houghton BF, McWilliams MO, Lanphere MA, Weaver SD, Briggs RM. Volcanic and structural evolution of Taupo Volcanic Zone, New Zealand, a review. Journal of Volcanology and Geothermal Research. 1995;68:1-28.

Wood C, Brathwaite RL, Rosenberg MD. Basement structure, lithology and permeability at Kawerau and Ohaaki geothermal fields, New Zealand. Geothermics. 2001;30:461-481. https://doi.org/10.1016/S0375-6505(01)00003-7 
Wyering LD, Villeneuve MC, Walli, IC, Siratovich PA, Kennedy BM, Gravley DM, Cant JL. Mechanical and physical properties of hydrothermally altered rocks, Taupo Volcanic Zone, New Zealand. 2014. https://doi.org/10.1016/j.jvolgeores.2014.10.008

Zoback MD, Byerlee JD. The effect of microcrack dilatancy on the permeability of Westerly granite. Journal of Geophysical Research. 1975;80:752-755. https://doi.org/10.1029/JB080i005p00752

The datasets used and analyzed during the current study are available and have been attached as submitting files. Information and settings about the machines employed in the experiments are available at Rock Deformation Laboratory - Department of Earth, Ocean and Ecological Sciences University of Liverpool (UK).

The authors declare that they have no competing interests regarding the publication of this article.

\section{Competing Interests}

This research was supported and funded by the New Zealand Ministry of Business, Innovation and Employment Geothermal Supermodels research programme hosted by GNS Science. 
Author's contributions

940

AM planned study strategy, made the rock samples for the tests, designed the jig for Brazilian test, performed all scientific experiments and measurements, analyzed and interpreted the experiments' data, observed thin sections at optical and SEM microscopes, built up graphs for the data interpretations, designed a schematic illustration of the sample assembly, made all the data tables presenting data collections, contributed in writing the manuscript.

DRF planned study strategy, supervised laboratory operations, analyzed and interpreted the experiments' data, contributed in writing the manuscript.

DDM planned study strategy, provided rough rock samples from the field, collected SEM images, analyzed and interpreted the experiments' data, contributed in writing the manuscript.

All authors read and approved the final manuscript.

\section{Acknowledgements}

We thank Julian Mecklenburgh for discussions of research results. We acknowledge the research staff and technicians of the University of Liverpool's Rock Deformation Laboratory (Gary Coughlan) and Scanning Electron Microscopy Shared Research Facility (Elliot Wood) for access to, use of, and training on equipment and microscopes.

\section{5} 67 


\section{Supplementary Files}

This is a list of supplementary files associated with this preprint. Click to download.

- Data.rar 